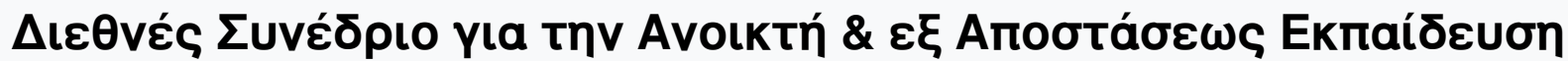

Tón. 8, Ap. 4B (2015)

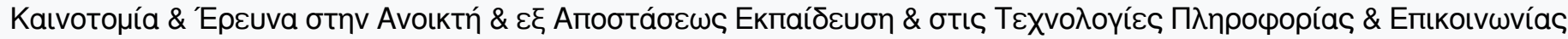

| ПраKüiká

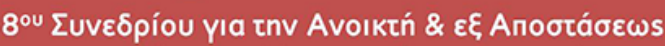

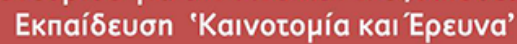

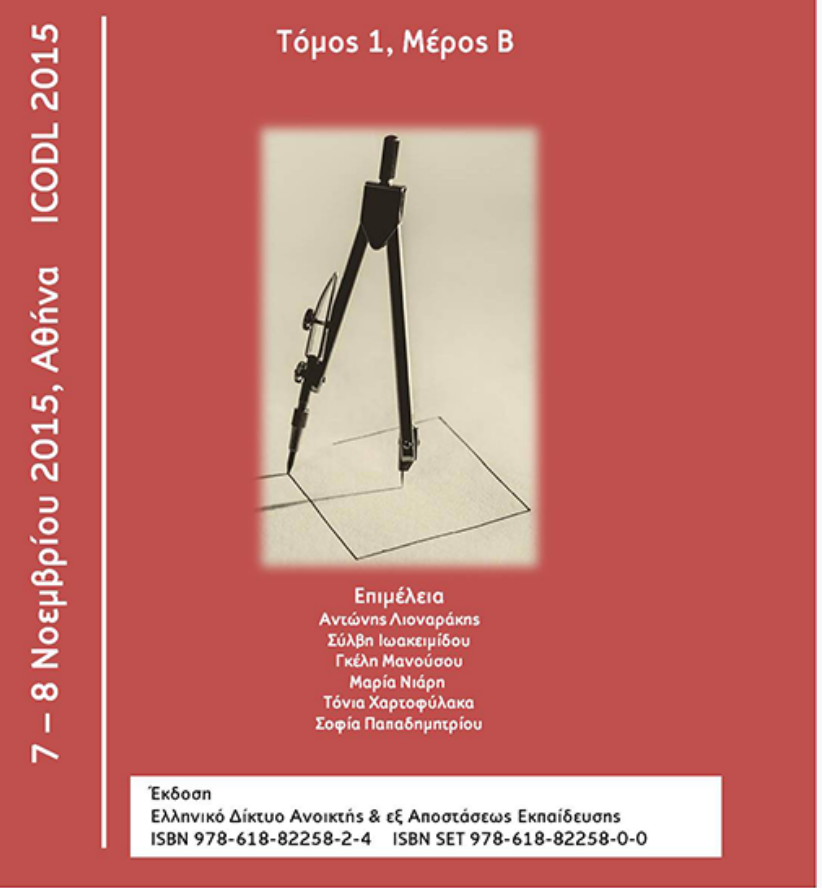

The usefulness of Tutorials and language machinimas in the Flipped TEFL/EAP Classroom (with interdisciplinary benefits in education)

Helena Galani

doi: $10.12681 /$ icodll.83 


\title{
The usefulness of Tutorials and language machinimas in the Flipped TEFL/EAP Classroom (with interdisciplinary benefits in education)
}

\author{
Helena Galani \\ Qualified English Language Adult Educator, \\ TEFL/EAP teacher, Oral Assessor, \\ LLL Centre, EFL centre, \\ CAMELOT Award winner 2015 (first prize) \\ EALTA, HAEA member \\ RSA Diploma, MA ELT \\ helenagalani@hotmail.com
}

\begin{abstract}
The aim of this paper is to outline how innovative online technologies can benefit TEFL and different levels of language education. The United Nations' proposed Sustainable Development plan for 2015-2030 includes "Ensuring inclusive and quality education for all and promoting lifelong learning" (Goal 4), "Building resilient infrastructure, promoting inclusive and sustainable industrialisation and fostering innovation" (Goal 9) to "End poverty in all its forms everywhere" (Goal 1), and to "Reduce inequality within and among countries" (Goal 10). To this end and from my capacity as CAMELOT Award winner in 2015, specific reference is made to the practical usefulness of tutorials and machinima through low cost technology, on virtual world platform and 'flipped classroom' to continue promoting educational principles at LLL Centres and in Foreign Language Education. The interdisciplinary use of tailor-made ELT machinimas together with tutorials and interchangeable forms of classroom patterns can substantially reduce fatigue on online courses while it caters for personalised, individualised and democratic educational processes in a learner centric, inclusive and holistic educational approach establishing self-directed learning. With encouragement, inclusion, and respect for the learner and the family, selforientated, active citizenship remains the immediate and long-term goal, for prompt dissemination of knowledge through compassion, cognition and consideration.
\end{abstract}

Key-words: TEFL/ EAP machinima, flipped classroom, virtual world, tutorials, inclusive, participatory

\section{Introduction}

Have you had misbehaving learners with discipline problems?

Have you ever had learners who assimilate less than half of the material you teach?

Have you ever had learners who finish earlier and are ready to take more initiative than others?

Have you ever had learners who have not developed the anticipated strategies and study skills on their course?

Has your online course created more problems than it promoted anticipated information? 
Has your online course exhausted its participants because it was fast-paced and cluttered with information?

Has your online course catered more for those who were 'digital dinosaurs', 'digital natives' (Donovan, 2011) or 'digital immigrants' (Prensky, 2001)? What has it done for your digital omnivores?

Have your online courses created little or no room for direct communication and consultation with your learners?

Not two classes are the same but every class is characterised by most of these.

Based on my past teaching experience as University EAP tutor with UK University but also to reflect on my experience as Adult Educator with the Lifelong Learning Centre in Lamia, I am here today to present the benefits of tutorials in all possible forms to enhance active learning and learner activation in a blended classroom. To promote the policies of "The Common European Framework of Reference for Languages (CEFR) and EU Key competences, I find the use of tutorials indispensable especially through flipped classrooms to satisfy "all individuals' need for personal fulfillment and development, active citizenship, social inclusion and employment" (European Commission, 2006).

For their interdisciplinary benefits at all stages of education and for all ages, I would like to urge educators and educationalists to stop being the centre of attention standing at the forefront of their classes. Instead of directing learners when to do what and where, there is a more open and accessible way to ensure that, apart from classroom support, they also have individualised support and ubiquitous access to the input material and the lesson at any time.

\section{Blended Learning and the flipped classroom}

Evidence by the US Department of Education suggests that BL generally leads to higher scores on summative and formative evaluations than fully online or face-toface classes (Means et al., 2010). With class time being devoted to constructivist activities, and purposeful interactions (Khan, 2012), face to face tutorials can strengthen the social skills and bond between participants as much as they can empower their language skills, progress and self-perception. Although course design and material structure in the flipped classroom may be the main hindrance, with substantial preparation time, it can be swift and cost-effective (Paulsen, 2009), it expands study time and provides learner opportunities for exponential learning, extensive practice and exposure to authentic instances in the target language.

Here are some of the multifold advantages of the 'flipped classroom':

- More learner centric - flexibly caters for needs - provides longer exposure to the target language

- Learner activity oriented with TBL \& PBL

- Material available on MOOC can be accessed at any time, which increases memory retention

- In class - monitoring progress, checking difficulties, diagnosing needs, setting the pace

- Multiple learning channels are employed to benefit all learning styles

- IT literacy \& skills develop simultaneously

- Active participation and immersion in the target language are encouraged

- Flow of instruction guided by learners creates motivation (Lage et al, 2000: 37)

- Instant feedback is provided on learner performance 
- The cost on instructional materials could be substantially reduced (Lage et al. 2000: 39). In 1994, Kozma predicted that opportunities for simulations would open up at a much lower cost than previously possible. It remains to be seen whether opportunities open up for cost effective tools to support the ideals of education.

- Caters for multiple intelligences

- Reduces drop-out rates

- Ensures learners follow the required pace

- Prevents online strain caused by e-interruptions and multitasking, and seclusion

- Increases concentration span

- Provides opportunities for cooperation, research skills and gradual scaffolding for complex cognitive tasks.

- Frees more time for individual personalised help with weaker learners while other classmates focus on their tasks (Davies et al., 2013).

\section{Tools}

On reflecting upon my own practical experience, towards implementation of flipped classroom techniques on ELT courses in Adult Education and Lifelong Learning programmes or on the three formal tiers of education, the following tools can prove beneficial:

- Class blog

- Electronic portfolios

- Online discussions

- Online surveys and quizzes

- Assignments, such as essays, worksheets, slide shows, photographs, and videos

- Online dropboxes \& drives

- Virtual World (Second Life)

- Email \& direct messages

- Video conferencing

- Moodle

- Videos \& tailor-made machinimas

- Blogging platform

- Online

- Individual \& small group tutorials

- Self-evaluation forms (educator \& learners) \& action plans

\section{Methods}

\section{Flipped classroom}

First, let us watch the following short HYPERLINK "https://www.youtube.com/watch?v=CXdsdpR24sQ" HYPERLINK "https://www.youtube.com/watch?v=CXdsdpR24sQ"video on what the flipped classroom is.

Reflecting on my professional experience, the term is best summarised as follows:

F for Flexible and Facilitative

L for Learner-centric

I for Interactive, Involving, Integrated and Individualised

$\mathrm{P}$ for Purposeful and Personalised 
The flipped classroom does not adhere to a single linear educational approach to fit all, but reverses the learning process by giving learners time to prepare before class time.

Davies et all (2013: 3) asserted:

Rather than the teacher providing synchronous in-class group instruction, students are expected to use the video/machinima resources provided, along with other materials, to learn concepts and complete tasks on their own at their own pace and at location convenient to the student.

Classroom time is used more creatively for TBL or PBL by reducing lecture, teachercentric time and providing opportunities for social interaction. Dewey advocated an education that empowers the learner. To Dewey (1916), a democratic classroom is active, social, is based on utility and therefore revolves around problem solving realworld issues. According to the same source, 'An education which should unify the disposition of the members of society would do much to unify society itself.' (Chapter 19)

Instead of checking, homework is done in class (Kathleen Fulton, 2012).

To stimulate learner research in preparation for casework, the learner is involved in the hands-on process of creating eye-catching visual materials to enhance memory \& language consolidation. Flipped classrooms 'actively transfer the responsibility and ownership of learning from the teacher to the students' and develop them into 'active learners rather than receptacles of information' (Bennett et al, 2011).

Open virtual environment can be used to establish the context for the new language to introduce, simulating sociolinguistic context recorded on a machinima. Second Life $\mathbb{R}$ is ideal for this.

To prevent loss of interest during a MOOC course, it helps to vary the activity types, their level of difficulty and to keep the technical tasks basic.

By allowing for interactivity and self-reflection during tutorials and by focusing more on practical solutions, learner self-confidence is further empowered. For instance, adding Badges certification to reward learner effort at each stage contributes to this.

Cooperative learning can be engaging even online (web conferencing, video calls, virtual world) through a combination of tools (Beldarrain, 2006; Vien, 2010).

Learners need involvement in interaction with their environment (real \& virtual) through content (cognition) to provide incentive (emotion) (Illeris, 2009).

Developing Writing skills plays an integral part towards establishing learner research skills as it "is a unique way of learning because it relates new knowledge to preview our experience, engaging students in the process of articulating ideas and re-coding knowledge graphically through language" (Fogleman, Niedbala, \& Bedell, 2013:76).

\section{Tutorials in the Flipped classroom}

In most higher education institutes in UK, the technique of academic tutorials is employed systematically to establish the validity of educational services on offer. Davis (in Jarvis, 2004) categorises tutorials into three types: supervision, group and practical.

For confidentiality and because of time restrictions, on short Adult Education courses ( 25 or 50 hours), the first type of tutorials is particularly useful and discreet focusing on individual learner educational needs. During this kind of face-to-face tutorial, the learner may be asked to prepare to discuss or reflect upon concepts or homework to smoother complexities. Alternatively, they could focus on diagnosing needs \& 
expectations, on improving language performance, communication and study skills, on recent test results and learning experiences, with the tutor preferably assuming a Socratic role to bring the learner to the fore and provide motivational support for effort even if performance is non optimal.

To sustain intrinsic motivation in the long term, paralinguistic cues can better provide feedback on the learner's motivational state (Lepper, 1993) on which to amplify extrinsic rewards (Eisenberger, 1992). This individualised, student-centred method cannot only be useful through face-to-face interaction and online conferencing tools on language adult courses but also on younger learners' courses for educational rather than therapeutic purposes.

With 'effort' being a direct indicator of motivation (Keller, 1983) the learner is persistently engaged in contributing to the top of their abilities. By increasing learner confidence, there are also more chances to experience success. However, excess of teacher intervention to provide simple reassurance could have the reverse effect. From personal experience though, with real or virtual life tutorials, it appears that after confidence has increased, initiative for independent study is amplified tirelessly. In fact, tutor attention is appreciated while the learner is more prepared to invest in time and energy for self-access study. Also during machinima preparation, even after task failure, the language learner is caught not to give up easily and to take initiative to restore the previous version of their homework willingly.

To help students emerge from learning difficulties and to ease the educational process, as quality assurance providers, educators can employ questionnaires, visuals, audiovisual material, extracts or even the in-world machinima of the tutorial with the learner in question. Also, learner opinions converging or diverging from common belief can be used around the roles in or functions of a class, unhealthy learning habits, improving memory and mnemonics, time management or preferred types of activities. 'Midwifery' techniques can also be adopted by fellow students to provide direct feedback on possible arising needs and the learning process. Jarvis (2004) characteristically states that a Socratic approach, as contrasted with a didactic one during tutorials, can bring better results.

This participatory, immersive, activating and, why not, emerging coaching technique can be used not only for academic feedback or in an exploratory or diagnostic way but also during the various stages of the course to re-examine, question, reflect upon or confirm firmly-rooted acceptances, to face anxiety and accomplish self-development. This type of educational language meeting does not replace counselling service to handle serious psychological conditions, disability or speech disorders which are better treated by special therapists with expertise, preparation and processing.

Rooted in constructivist (Piaget, Vygotsky) and situated cognition theories (with antecedents in the work of Gibson, 1979) on which home-tutoring is based, tutorials similarly to language machinima production - promote knowledge in the form of continuous evolution emerging from perceiving and acting, from action and interaction between the agent and the environment (Lave \& Wenger, 1991). Learning is based on doing which is reflected in classroom processes orbiting around Problembased Learning, Project-based Learning, Task-based Learning (Thomas, 2010) and Cognitive Apprenticeship by making use of social and physical context to enhance reflection, cognition and reciprocity (Collins, Brown \& Newman, 1989).

Whichever channel of tuition is selected, as animator and mediator, the educator-tutor coordinates the learning process through respect for individual freedom based on the idea of equal opportunities as suggested by Kokkos (Kóкко૬, 2005), to assist their 
learners with reaching their highest aptitude during an accelerated language acquisition process.

\section{EFL/EAP Machinima in the Flipped Classroom}

Educational machinima is one method of instilling learner autonomy through PBL in Virtual World (VW) or in the physical classroom, for synchronous, asynchronous instruction or self-access learning.

They are memorable \& tailor-made.

They are appropriate for all stages and types of lessons.

They are based on motivational tasks through a holistic approach to learning.

They are inspiring \& immersive linguistically, socially, technologically and emotionally.

They encourage language production in context.

They help learners apply their existing knowledge for a purpose.

They help activate existing skills and cultivate new ones.

They bring out learners' full potential.

They engage in meaningful preparation and presentation of what learners have grasped or need to grasp.

They can bring the textbook to life as classes in VW Second Life do (Sadler \& Dooly, in Thomas, 2013)

They promote 'learning by being, learning by building, learning by exploring, learning by collaborating, learning by championing, learning by expressing' (Lim's 'Six Learnings of Second Life' in Rainbow \& Schneider, 2014).

They create 'flow' and a steady pace of learning and participation.

Through tailor-made language machinima in virtual worlds, the educator-tutor offers opportunities for 'experiential learning' an 'episodic experience of what they [students] have been learning or what they are about to experience when they enter the world of work' (Jarvis, 2010, p. 174). As pointed out by Jarvis, experiential learning situations can be 'artificial' instances mirroring everyday life to provide primary experiences, a sense of reality, and a more realistic exposure than attendance at the lecture theatre. This is where machinima, as a form of new literacy, comes in to support language lessons (L1 or foreign) with discourse use in socio-cultural contexts on what Gibson (1979, in Gieseking et al) names a continuous 'perceiving and acting' cycle. By encouraging perception of positive affordances with 'value-rich' messages, a term used by Gibson (1979), the educator-tutor leads the learner to observation, confidence and limitless opportunities to actively take charge of their own learning, work and life.

With educational machinima and learning or acting out in an open virtual world where 'information is available in ambient light for perceiving' (Gibson, 1979), selfdirected learning is seen as a participatory educational ritual absorbing the learner in the 'flow' of learning and developing study skills and strategies.

As far as approaches to holistic learning are concerned, Jarvis asserts that this is 'the combination of processes whereby the whole person - body (genetic, physical and biological) and mind (knowledge, skills, attitudes, values, emotions, beliefs and senses) - is in a social situation and constructs an experience which is then transformed cognitively, emotively or practically (or through any combination) and integrated into the individual's own biography'. (Jarvis, 2010: 7). With self-directed learning considered as Knowles' main concept of andragogy, working towards higher degrees of autonomy is ideally any learner's short and long term aim. By realizing 
the connection between situated cognition and experiential learning through new technological literacy, an essential landmark is added in the educational domain. In particular, machinima-creation on Second Life can be an indispensable part in every class providing meaningful and memorable opportunities for language use in virtually social contexts.

If people remember $90 \%$ of what they do, opportunities to prepare simulations and three-minute educational machinima contribute to linguistic memory retention and encourage language in use.

If people remember $50 \%$ of what they hear and see, then learners can be involved in the design of an e-course based on audio \& video/machinima material in a virtual world. By employing the processes of machinima use, the learner engages in visual, oral and audio learning tasks studying the aspects of meaning and language use that are dependent on the speaker, the addressee and specific features of the utterance such as principles of communication, speaker goals, context of the utterance, turns of conversation and relations of meaning between portions of discourse.

Even if there is no scientific evidence backing up the percentage proportions around Dale's 'Cone of Experience' (1969), from an empirical point of view I realise that, as a medium of meaningful, associative and active learning, learner involvement in the creation of machinima on SL supports memorisation through integration of skills and linkages between aspects of teachers' language during instruction and learners' use of mnemonic strategies to strengthen memory development and retention. By going beyond the level of rote memorisation of grammar rules and word lists, learners of all ages and abilities grasp the hidden messages of the language and take control of their own learning through hands-on application of their newly acquired knowledge.

Besides, 'research confirmed that students' satisfaction with learning in virtual worlds like Second Life was high when using authentic tasks, and argued that learners reported on significant opportunities for enhanced levels of engagement in online environments' (Schwienhorst, in Thomas, 2010a) for problem-solving, collaborative learning, knowledge-building and role playing activities.

With particular reference to my professional experience, it seems that personally relevant and emotionally salient material is easier to recall and eventually consolidate on SL. Justifiably, in a virtual environment providing a clear account of 'effectivities' and 'affordances' where 'mutuality' between objects strengthens perception (Gibson, 1979: 22), "the 'values' and 'meanings' of things in the environment can be directly perceived” (Gibson, 1979: 127).

\section{The big challenge}

The following are major challenges that need to be addressed when attempting to merge online ICT tools in the physical class.

- The suggested process of online MOOCs takes increased preparation time \& technological know-how considering its tailor-made nature to cater for different learner needs.

- It could be costly and time consuming to train teachers to use the technology, unless they are self-directed and digitally literate, already taking initiative.

- A clear pedagogy and eclectic educational approaches are required on which to construct the language course. 


\section{Measures}

To overcome possible hindrance, course providers could activate native, self-directed, IT literate language teachers who exhibit both subject-specific and technical skills to teach the language through the suggested New Technologies and train colleagues in the creation of machinima and flipped learning techniques.

The use of a virtual world (Second Life, for 16+) could be employed to moderate and coordinate learning in combination with an online platform and/or physical classroom presence.

To avoid the danger of using technology for the sake of it on a language course, a task-based approach to teaching as suggested by Ellis (in Thomas, 2010b) can direct focus on making meaning, engaging with real-life language use, language skills development, and cognitive with metacognitive engagement towards completion of the goal for a communicative purpose.

Learner competences and attitude can be better inspired through the use of new technologies for learning, development of life skills, employability and for productivity. As quality assurance begins in the classroom and is led by the educator, a combination of affective, cognitive and psychomotor lesson aims need to be brought to the forefront to sensitise learners as members of their community and promote social inclusion and active citizenship in a globalised setting.

\section{Conclusion}

The implementation of tutorials and educational machinima development on virtual world combined with flipped classroom techniques, as core educational tools, can effectively enhance the three levels of formal educational systems and all folds of lifelong learning. This does not only come to support the ongoing need for linguistic communication, reflection and prompt dissemination of knowledge with information but also it encourages participatory processes, inclusion, compassion, mutualism and civil society. In order to gain a complete understanding of its practical use, implementation of the proposed approach can demonstrate its long-term efficacy and usefulness on the continuum of Education and Adult Learning and Education. As "education and the exercise of virtue, above all, lead to an honourable life" (Aristotle), lifelong support, partnerships and entrepreneurialism can strengthen Human Resources and further nourish the family unit in the context of globalisation.

\section{References}

Beldarrain, Y., (2006). Distance Education Trends: Integrating new technologies to foster student interaction and collaboration. Distance Education, 27(2), 139-153.

Collins, A., Brown, J., \& Newman, S. (1989). Cognitive Apprenticeship: Teaching the craft of reading, writing and mathematics. In L. B. Resnick (Ed.), Knowing, learning, and instruction: Essays in honor of Robert Glaser. Hillsdale, NJ: Erlbaum

Common European Framework Of Reference For Languages: Learning, Teaching, Assessment. Council of Europe. Strasburg: Language Policy Unit. Retrieved from Dale, Edgar. (1969). Audio-Visual Methods in Teaching, 3rd ed. New York: Holt, Rinehart \& Winston. Retrieved from http://www.coe.int/t/dg4//inguistic/Source/Framework_EN.pdf HYPERLINK "http://www.coe.int/t/dg4/linguistic/Source/Framework_EN.pdf\%20on\%2019/9/2015"on 19/9/2015

Davies, R. S., Dean, D. L., \& Ball, N. (2013). Flipping the classroom and instructional technology integration in a college-level information systems spreadsheet course. Educational Technology Research and Development, 61(4), 563-580. doi:10.1007/s11423-013-9305-6

Dewey, J. (1916). Democracy \& Education. ILT Digital Classics. Retrieved from https://en.wikisource.org/wiki/Democracy_and_Education on 19/9/2015 
Donovan, M. "The Rise of Digital Omnivores". comScore. 12/12/2011

Eisenberger, R. (1992). Learned industriousness. Psychological Review, 99, 248-267

European Commission (2006). Key competences for Lifelong Learning - European Reference $\begin{array}{lllll}\text { Framework. } & \text { Retrieved } & \text { October } & 2013 & \text { from: }\end{array}$ http://ec.europa.eu/dgs/education_culture/publ/pdf/ll-learning/keycomp_en.pdf

European Commission/EACEA/Eurydice (2012). Developing Key Competences at School in Europe: Challenges and Opportunities for Policy. Eurydice Report. Luxembourg: Publications Office of the European Union, ISBN 978-92-9201-292-2, doi:10.2797/93204, Retrieved 7 October 2013

from: http://eacea.ec.europa.eu/education/eurydice/documents/thematic reports/145EN.pdf

Fulton, K. (2012). Upside down and inside out: Flip your classroom to improve student learning. Learning \& Leading with Technology, 39(8), 12-17 retrieved from http://files.eric.ed.gov/fulltext/EJ982840.pdf on 19/9/2015

Galani, H. (2015) The Flipped Classroom retrieved from https://www.youtube.com/watch?v=CXdsdpR24sQ on 27/10/2015

Gardner, H. (1993). Multiple Intelligences: The Theory in Practice. New York: Basic

Garrison, D. R., \& Kanuka, H. (2004). Blended learning: Uncovering its transformative potential in higher education. The Internet and Higher Education, 7, 95-105.

Gee, J. P. (2004). Situated Language and learning: A critique of traditional schooling. London: Routledge

Gibson, J.J. (1979). The Ecological Approach to Visual Perception. Boston: Houghton Mifflin.

Gibson, J. J. The Theory of Affordances. In Gieseking, J. J., Mangold, W., Katz, C., Low, S., Saegert, S. (Eds) (2014). The People, Place and Space Reader (pp. 56-60). London, Routledge

Illeris, K. (2009). Contemporary Theories of Learning: Learning Theorists ... In Their Own Words. London: Routledge

Illeris, K. in Jarvis, P \& Parker, S. (2007). Human Learning: An Holistic Approach. London: Routledge Jarvis P. (2004). Adult Education and Lifelong Learning: Theory and Practice. New York: Routledge

Keller, J. M. (1983). Motivational design of instruction. In C. M. Reigeluth (Ed.), Instructional-Design Theories and Models: An Overview of their Current Status (pp. 386-434). Hillsdale, NJ: Lawrence Erlbaum Associates

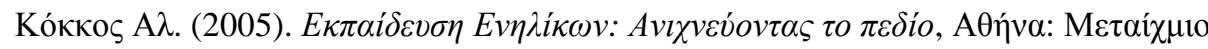

Kozma, R. B. (1994). Will media influence learning? Reframing the debate. Educational Technology Research and Development, 42(2), 7-19. Retrieved from http://robertkozma.com/images/kozma_will_media_influence.pdf on 19/9/2015

Lage, M. J., Platt, J. G. \& Treglia, M. (2000). Inverting the Classroom: A Gateway to Creating an Inclusive Learning Environment. 'The Journal of Economic Education' Vol. 31, No. 1, pp. 3043

Lave, J., \& Wenger, E. (1991). Situated Learning: Legitimate Peripheral Participation. Cambridge: Cambridge University Press

Lepper, M. R., Woolverton, M., Mumme, D., \& Gurtner, J. (1993). Motivational techniques of expert human tutors: Lessons for the design of computer-based tutors. In S. P. Lajoie \& S. J. Derry (Eds.), Computers as cognitive tools. Hillsdale, NJ: Lawrence Erlbaum Associates

Means, B., Yoyama, Y., Murphy, R., Bakia, M., \& Jones, K. (2010). Evaluation of evidence-based practices in online learning: A meta-analysis and review of online learning studies. US Department of Education. Retrieved from http://www2.ed.gov/rschstat/eval/tech/evidencebased-practices/finalreport.pdf

Paulsen, M. F., (2009). Successful E-Learning in small and medium-sized enterprises. European Journal of Open and Distance Learning pp. 1-9. Retrieved 19/9/2015 from http://www.eurodl.org/materials/contrib/2009/Morten_Paulsen.pdf

Piaget, Jean. (1950). The Psychology of Intelligence. New York: Routledge

Prensky, Marc (October 2001). "Digital Natives, Digital Immigrants". On the Horizon 9 (5): 1-6.

Schneider, C. \& Rainbow, C. (2014). Making and Using Machinima in the Language Classroom. The Round. Retrieved from http://the-round.com/resource/making-and-using-machinima-in-thelanguage-classroom/

Thomas, M. (2010). Task-based Language Teaching and Collaborative Problem-solving with Second Life: A Case Study of Japanese EFL Learners. International Conference ICT for Language Learning. Retrieved from http://conference.pixelonline.net/ICT4LL2010/common/download/Proceedings_pdf/IBL54-Thomas.pdf on 19/9/2015 
$8^{\text {th }}$ International Conference in Open \& Distance Learning - November 2015, Athens, Greece - PROCEEDINGS

Thomas, M. \& Reinders, H. (eds) (2010). Task-Based Language Learning and Teaching with Technology. London: Continuum

Thomas, M., Reinders, H. \& Warschauer, eds (2013). Contemporary Computer-Assisted Language Learning. London: Bloomsbury Academic

Vygotskii, L.S. (1978). Mind in society: The development of higher mental processes. Cambridge, MA: Harvard University Press 